\title{
A Review of Mercury Bioavailability in Humans and Fish
}

\author{
Mark A. Bradley ${ }^{1}$, Benjamin D. Barst ${ }^{2}$ and Niladri Basu ${ }^{1,2, *}$ \\ 1 School of Dietetics and Human Nutrition, McGill University, Montréal, QC H3A 0G4, Canada; \\ mark.a.bradley@mail.mcgill.ca \\ 2 Department of Natural Resource Sciences, McGill University, Montréal, QC H3A 0G4, Canada; \\ benjamin.barst@mcgill.ca \\ * Correspondence: niladri.basu@mcgill.ca; Tel.: +1-514-398-8642
}

Academic Editor: Paul B. Tchounwou

Received: 30 November 2016; Accepted: 4 February 2017; Published: 10 February 2017

\begin{abstract}
To estimate human exposure to methylmercury (MeHg), risk assessors often assume $95 \%-100 \%$ bioavailability in their models. However, recent research suggests that assuming all, or most, of the ingested mercury $(\mathrm{Hg})$ is absorbed into systemic circulation may be erroneous. The objective of this paper is to review and discuss the available state of knowledge concerning the assimilation or bioavailability of $\mathrm{Hg}$ in fish and humans. In fish, this meant reviewing studies on assimilation efficiency, that is the difference between ingested and excreted $\mathrm{Hg}$ over a given period of time. In humans, this meant reviewing studies that mostly investigated bioaccessibility (digestive processes) rather than bioavailability (cumulative digestive + absorptive processes), although studies incorporating absorption for a fuller picture of bioavailability were also included where possible. The outcome of this review shows that in a variety of organisms and experimental models that $\mathrm{Hg}$ bioavailability and assimilation is less than $100 \%$. Specifically, 25 studies on fish were reviewed, and assimilation efficiencies ranged from $10 \%$ to $100 \%$ for $\mathrm{MeHg}$ and from $2 \%$ to $51 \%$ for $\mathrm{Hg}$ (II). For humans, 20 studies were reviewed with bioaccessibility estimates ranging from $2 \%$ to $100 \%$ for $\mathrm{MeHg}$ and $0.2 \%$ to $94 \%$ for $\mathrm{Hg}$ (II). The overall absorption estimates ranged from $12 \%$ to $79 \%$ for $\mathrm{MeHg}$ and $49 \%$ to $69 \%$ for $\mathrm{Hg}(\mathrm{II})$, and were consistently less than $100 \%$. For both fish and humans, a number of cases are discussed in which factors (e.g., Hg source, cooking methods, nutrients) are shown to affect $\mathrm{Hg}$ bioavailability. The summaries presented here challenge a widely-held assumption in the $\mathrm{Hg}$ risk assessment field, and the paper discusses possible ways forward for the field.
\end{abstract}

Keywords: methylmercury; inorganic mercury; biological availability; bioaccessibility; assimilation; biological transport; seafood; cooking; gastrointestinal tract

\section{Introduction}

Humans and wildlife are primarily exposed to methylmercury $(\mathrm{MeHg})$ through the consumption of foods with elevated $\mathrm{Hg}$ concentrations [1,2]. Although MeHg sources may differ for certain human populations (e.g., pilot whale for Faroese [3,4]; rice for inland Chinese [5]), seafood represents the predominant pathway of $\mathrm{MeHg}$ exposure for most humans [6]. It is widely acknowledged that $\mathrm{MeHg}$ exposure occurs worldwide [7], and that real-world exposures have the potential to affect both human [8] and ecosystem health [2]. Accordingly, the Minamata Convention on Mercury was signed to protect human and ecosystem health from anthropogenic emissions and releases of mercury $(\mathrm{Hg})$ and $\mathrm{Hg}$ compounds.

Balancing the risks of $\mathrm{MeHg}$ exposure versus the benefits associated with seafood consumption is vital given that seafood is also an important source of animal protein for much of the world's population and there are many health benefits associated with its consumption $[9,10]$. To estimate 
human exposure to $\mathrm{MeHg}$, risk assessors use standard models that incorporate the concentration of $\mathrm{MeHg}$ in a given seafood type along with self-reported information on portion size and consumption frequency [11]. These models include a correction factor to account for the proportion of $\mathrm{MeHg}$ estimated to reach systemic circulation, and make the assumption that $95 \%$ to $100 \%$ of the ingested $\mathrm{MeHg}$ is bioavailable. However, recent research suggests that assuming all, or most, of the ingested $\mathrm{MeHg}$ is absorbed into systemic circulation may be erroneous. This may result in inaccurate estimations of exposure (and ultimately risk), and as such may hamper our ability to properly balance the potential risks and benefits of seafood consumption.

The objective of this paper is to review and discuss the available state of knowledge concerning the assimilation or bioavailability of $\mathrm{MeHg}$ in fish and humans. Given the importance of fish as a vector for $\mathrm{MeHg}$ exposure in humans, but also a target for MeHg poisoning themselves, we first review studies regarding $\mathrm{Hg}$ assimilation in fish. Next, we review the evidence of $\mathrm{Hg}$ bioavailability from human-based studies. In general, peer-reviewed published papers were identified which report assimilation efficiencies or bioavailability of either $\mathrm{Hg}(\mathrm{II}), \mathrm{MeHg}$, or both forms of $\mathrm{Hg}$ in fish and humans following dietary exposure.

For fish, dietary Assimilation Efficiencies (AE) are generated by measuring the amount of a chemical retained by fish after dietary exposure of a known quantity of food, and represent the net result of absorption and elimination processes [12]. Dietary AEs for fish are typically calculated as the percentage of $\mathrm{Hg}$ (II) or $\mathrm{MeHg}$ retained after a specific period of exposure and/or depuration. To review the state of knowledge concerning $\mathrm{Hg}$ AEs in fish, two separate literature searches were performed with SCOPUS indexing service with the last search performed on 22 October 2016. The first search was performed with the following search terms:

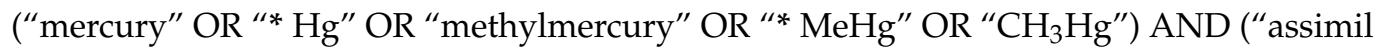
* efficiency" OR "intestine * transfer" OR "gut" OR "uptake pathway") AND "fish".

The second search included the terms:

“203 $\mathrm{Hg}^{\prime}$ AND ("accumulation" OR "diet") AND "fish".

For both searches, the terms "rat", "mice", "bird", "human", "women", "men", and "children" were excluded. A total of 108 studies were identified for the two searches. Of these, 25 studies reported dietary AEs for $\mathrm{Hg}(\mathrm{II})$ and / or $\mathrm{MeHg}$ and are reviewed here.

For the human section, we focused on bioavailability (Figure 1; [13]) which refers to the fraction of an ingested compound that reaches systemic circulation and is thus available for biological activity. To review the state of knowledge concerning $\mathrm{Hg}$ bioavailability in humans, three separate literature searches were performed with SCOPUS indexing service with the last search performed on 24 October 2016. The first search was performed with the following terms:

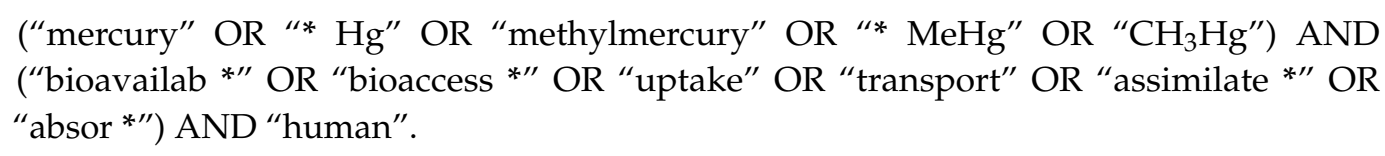

The second search included the terms:

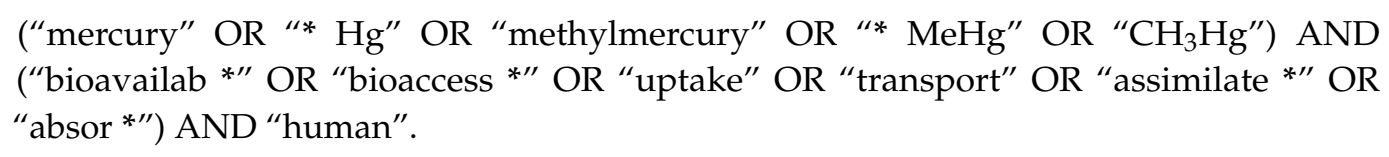

The third search included the terms:

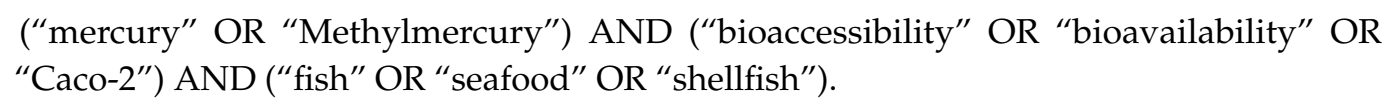


For all searches, the terms "Soil" and "Air Pollution" were excluded. A total of 115 studies were identified for the two searches, of which 20 reported on some aspect of bioavailability for $\mathrm{Hg}(\mathrm{II})$ and /or $\mathrm{MeHg}$, which were the focus of this section.

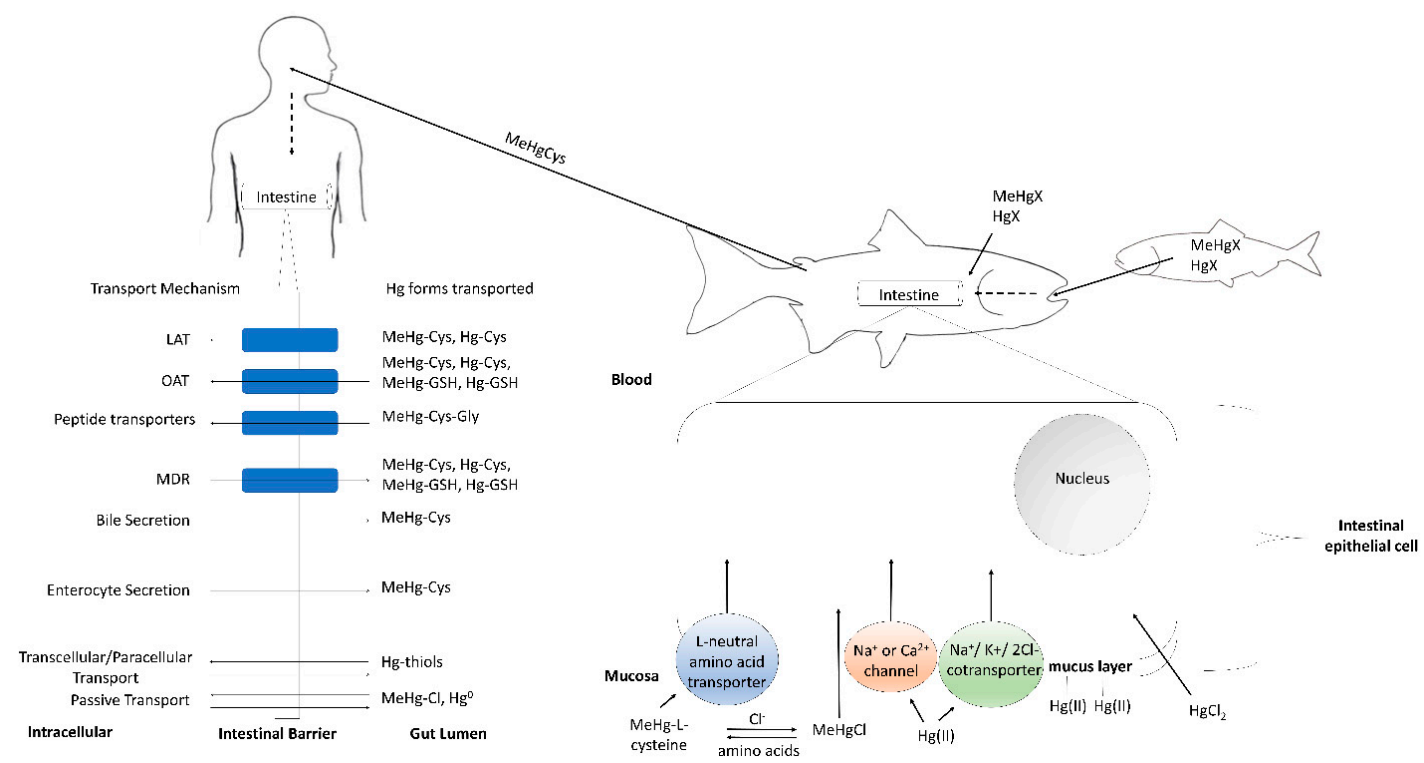

Figure 1. Model for methylmercury (MeHg) and inorganic mercury ( $\mathrm{Hg}(\mathrm{II}))$ uptake across fish and human intestinal epithelial cells. Exposure to $\mathrm{Hg}(\mathrm{II})$ and $\mathrm{MeHg}$ occurs mainly through diet. $\mathrm{Hg}$ in both water and biological systems is bound to ligands (" $X$ "). MeHg in fish muscle is predominately stored as MeHg-Cys [14], which enters intestinal epithelial cells through energy dependent L-type neutral amino acid transporters (LAT). $\mathrm{MeHgCl}$ may also enter the cell by diffusion, or by non-specific active uptake mechanisms of $\mathrm{MeHg}$ complexes (not shown). MeHg-Cys dominates when complexing amino acids are present [15]. Uptake of $\mathrm{Hg}$ (II) is presented as the model proposed by Hoyle and Handy [16]. $\mathrm{Hg}$ (II) may enter through voltage-gated $\mathrm{Na}^{+}$or $\mathrm{Ca}^{2+}$ channels, through the $\mathrm{Na}^{+} \mathrm{K}^{+} 2 \mathrm{Cl}^{-}$ cotransporter, and/or by diffusion of $\mathrm{HgCl}_{2}$. Uptake of anionic $\mathrm{Hg}$ complexes $\left(\mathrm{HgCl}_{4}{ }^{2-}\right)$ may be possible by anionic exchange (not shown). The mucus lining the gut has a high affinity for $\mathrm{Hg}(\mathrm{II})$ ions, thus limiting uptake [17]. Many of the same mechanisms occur in the human gut following $\mathrm{MeHg}$ ingestion through consumption of fish, with LAT playing a prominent role in transporting MeHg-Cys, while other peptide transporters and the organic anion transporter (OAT) may also contribute to uptake of MeHg-Cys (as reviewed by Bridges and Zalups [18]) Arrows are indicative of direction of transport.

\section{Fish}

Wild fish are exposed to $\mathrm{Hg}$ (II) and $\mathrm{MeHg}$ in both water and food. Uptake of $\mathrm{MeHg}$ from diet accounts for approximately $80 \%$ to $90 \%$ of total uptake, with the remaining fraction coming from water $[19,20]$. Uptake of $\mathrm{Hg}$ (II) from diet (predicted by ${ }^{203} \mathrm{Hg}$ radiotracer studies in tilapia) is more variable and may account for $32 \%$ to $92 \%$ of the total $\mathrm{Hg}$ (II) accumulation, with the remainder being absorbed from water [21]. The uptake of $\mathrm{Hg}$ (II) across the gills is dependent on water chemistry; increases in dissolved organic carbon (DOC) decrease uptake [22,23] while chloride concentrations that favor the production of $\mathrm{HgCl}_{2}$ increase absorption [23]. Though exposure to $\mathrm{Hg}$ (II) and $\mathrm{MeHg}$ via water may be more important under certain circumstances (i.e., when fish are not feeding), it is generally accepted that dietary uptake is the most important exposure pathway for fish.

Both $\mathrm{MeHg}$ and $\mathrm{Hg}(\mathrm{II})$ have strong binding affinities for selenium and sulfur, which within biological systems are mostly present as selenols and thiols. Cysteine (Cys) represents the most abundant protein- or peptide-bound thiol in biological systems [24], and is the major complexing agent in fish muscle tissue [14]. As a result, dietary uptake of Hg-thiol complexes in the gut is an important process which dictates the assimilation of $\mathrm{MeHg}$ by fish. Uptake of MeHg-L-Cys in the 
fish gut most likely occurs through energy-dependent large L-type neutral amino acid transporters (LAT) [15]. Uptake of $\mathrm{MeHgCl}$, which predominates when cysteine and other amino acids are absent, may occur through passive diffusion and non-specific active mechanisms [15]. Further research is required to elucidate the potential non-specific active mechanisms involved in the uptake of $\mathrm{MeHg}$ complexes; however, transport across the intestine decreases with temperature or ouabain, an inhibitor of active transport by $\mathrm{Na}^{+}, \mathrm{K}^{+}$-ATPase pumps [15] (Figure 1).

After studying the absorption of $\mathrm{Hg}(\mathrm{II})$ across isolated intestines of rainbow trout, Hoyle and Handy [16] developed a tentative working model for $\mathrm{Hg}$ (II) transfer across the vertebrate intestine (reviewed by Kidd and Batchelar [25]). The authors suggest that uptake of $\mathrm{Hg}(\mathrm{II})$ across the intestines may enter cells through voltage-gated $\mathrm{Ca}^{2+}$ channels, and/or by diffusion of electroneutral complexes, such as $\mathrm{HgCl}_{2}$. Furthermore, uptake of anionic $\mathrm{Hg}$ complexes may be possible by anionic exchange. Despite these various possible uptake routes, the mucosal membrane lining the gut has been shown to serve as an excellent barrier to $\mathrm{Hg}$ (II), as $\mathrm{Hg}$ (II) ions are efficiently bound to mucus at physiological $\mathrm{pH}$ [17] (Figure 1). This is consistent with a study of rainbow trout (Oncorhynchus mykiss) gut sacs perfused with $\mathrm{HgCl}_{2}$ solution which demonstrated that the majority $(78 \%-85 \%)$ of $\mathrm{Hg}(\mathrm{II})$ accumulated in intestinal mucosa rather than in underlying tissue [16]. Boudou and Ribeyre [26] reported that following 30 days dietary exposure to $\mathrm{HgCl}_{2}, 36 \%$ of the relative $\mathrm{Hg}(\mathrm{II})$ burden accumulated in the posterior intestines of rainbow trout. In a separate group of rainbow trout exposed to dietary $\mathrm{MeHgCl}$ for 30 days, less than $3 \%$ of the relative $\mathrm{Hg}$ (II) burden was found in posterior intestines. Thus, significant fractions of ingested $\mathrm{Hg}$ may localize largely in the intestinal mucosa and in the posterior intestines of fish.

We identified 25 studies which report dietary AEs for $\mathrm{Hg}(\mathrm{II}), \mathrm{MeHg}$, or both (Figure 2; Table S1), all conducted in vivo. Fifteen of the studies report dietary AEs for both $\mathrm{Hg}$ (II) and MeHg. Sixteen of the 25 studies used radioisotopes $\left({ }^{203} \mathrm{Hg}\right.$ and $/$ or ${ }^{203} \mathrm{MeHg}$ ) as sources of $\mathrm{Hg}$ (II) and $\mathrm{MeHg}$ in their experiment(s). Seven studies used the chloride complexes $\mathrm{HgCl}_{2}$ and $/$ or $\mathrm{MeHgCl}$, and two studies used naturally-contaminated fish. Various food types were used to transfer $\mathrm{Hg}$ (II) and/or $\mathrm{MeHg}$ to the study fish. Nine studies report AEs from multiple food types. The tested food types included prepared fish food (including artificial and commercial foods, as well as fish meal prepared by the researchers; 11 of 25), invertebrates (13 of 25), previously exposed fish or fish parts (5 of 25), algae ( 3 of 25 ), and sediment ( 1 of 25). The studies ranged in duration from $36 \mathrm{~h}$ to 4 months in length, and reported dietary AEs for 21 different species of freshwater, marine, or euryhaline fish.

There was considerable variation among the reported dietary AEs for $\mathrm{MeHg}$ and $\mathrm{Hg}$ (II). AEs for $\mathrm{MeHg}$ were $10 \%-100 \%$ and for $\mathrm{Hg}$ (II) were $2 \%-51 \%$ (Figure 2). In general, dietary $\mathrm{MeHg}$ was more efficiently assimilated than $\mathrm{Hg}$ (II). Several of the studies indicated differences in AEs among food types. For example, sweetlips (Plectorhinchus gibbosus) which consumed either brine shrimp (Artemia sp.), copepods (Acartia spinicauda), or silverside (Atherion elymus) contaminated with $\mathrm{Hg}$ radioisotopes assimilated $56 \%-95 \%$ and $10 \%-27 \%$ of $\mathrm{MeHg}$ and $\mathrm{Hg}(\mathrm{II})$, respectively [27]. Similarly, Goto and Wallace [28] reported differences in MeHg AEs (52\%-89\%) after feeding mummichog (Fundulus heteroclitus) one of several diets of contaminated aquatic invertebrate or fish. Dutton and Fisher [29] reported low dietary $\mathrm{AEs}$ for $\mathrm{Hg}$ (II) (2\%-4\%) and $\mathrm{MeHg}(10 \%-14 \%)$ after feeding killifish spiked sediments (195 nM ${ }^{203} \mathrm{Hg}$ (II) and $195 \mathrm{nM}^{203} \mathrm{MeHg}$ ). As a comparison, the authors also exposed a separate group of killifish to contaminated algae (2.01 nM ${ }^{203} \mathrm{Hg}$ (II) and $2.01 \mathrm{nM}{ }^{203} \mathrm{MeHg}$ ). Dietary AEs were significantly greater for both $\mathrm{Hg}$ (II) $(18 \%)$ and $\mathrm{MeHg}(82 \%)$ from this food type, which the authors suggest was due to metal binding to more labile organic matter in algae, thus increasing the bioavailability.

There is some evidence which suggests that AEs of MeHg may be concentration and/or time dependent. After 35 days of dietary MeHg exposure, Sacramento blackfish (Orthodon microlepidotus) in the high-dose group $(55.5 \mu \mathrm{g} / \mathrm{g}$ ) had assimilated a significantly lower percentage of $\mathrm{MeHg}$ in muscle than those in the low-dose group $(0.52 \mu \mathrm{g} / \mathrm{g})$. However, after 75 days of exposure AEs were lower, but not significantly different among the treatment groups, which the authors suggested may have been 
due to decreased absorption, increased depuration, or a combination of the two [30]. In a separate study by Rodgers and Beamish [31], AE decreased from $70 \%$ to $80 \%$ to less than $50 \%$ in rainbow trout exposed to dietary $\mathrm{MeHg}(75 \mu \mathrm{g} / \mathrm{g})$ for 9 weeks. In general, a decline in AE after prolonged exposure to a chemical would be expected as a dynamic steady state is reached [12].

Naturally-contaminated fish or fish muscle (that is, fish that have been contaminated with $\mathrm{Hg}$ in the natural environment, or muscle collected from such fish) have rarely ( 2 of 24 studies) been used as a source of $\mathrm{Hg}$ in studies reporting AEs for either $\mathrm{MeHg}$ or $\mathrm{Hg}$ (II) (Figure 2). Li et al. [32] incorporated muscle of feral fish from contaminated systems (catfish (Ictalurus punctatus) for high $\mathrm{Hg}$ exposure or walleye (Sander vitreus) for low $\mathrm{Hg}$ exposure) into food pellets for goldfish (Carassius auratus), and reported an $\mathrm{AE}$ of $98 \%$ regardless of experimental $\mathrm{Hg}$ exposure. Conversely, Northern pike (Esox lucius) assimilated only 19\% of the $\mathrm{MeHg}$ from wild-caught common carp (Cyprinus carpio) used as feeder fish [33]. To our knowledge, the latter is the only study to report an $\mathrm{AE}$ of $\mathrm{MeHg}$ after using naturally-contaminated whole feeder fish. More studies that use naturally-contaminated whole feeder fish are needed in order to assess whether MeHg bioavailability is overestimated by studies using spiked diets or those using laboratory-exposed prey fish.

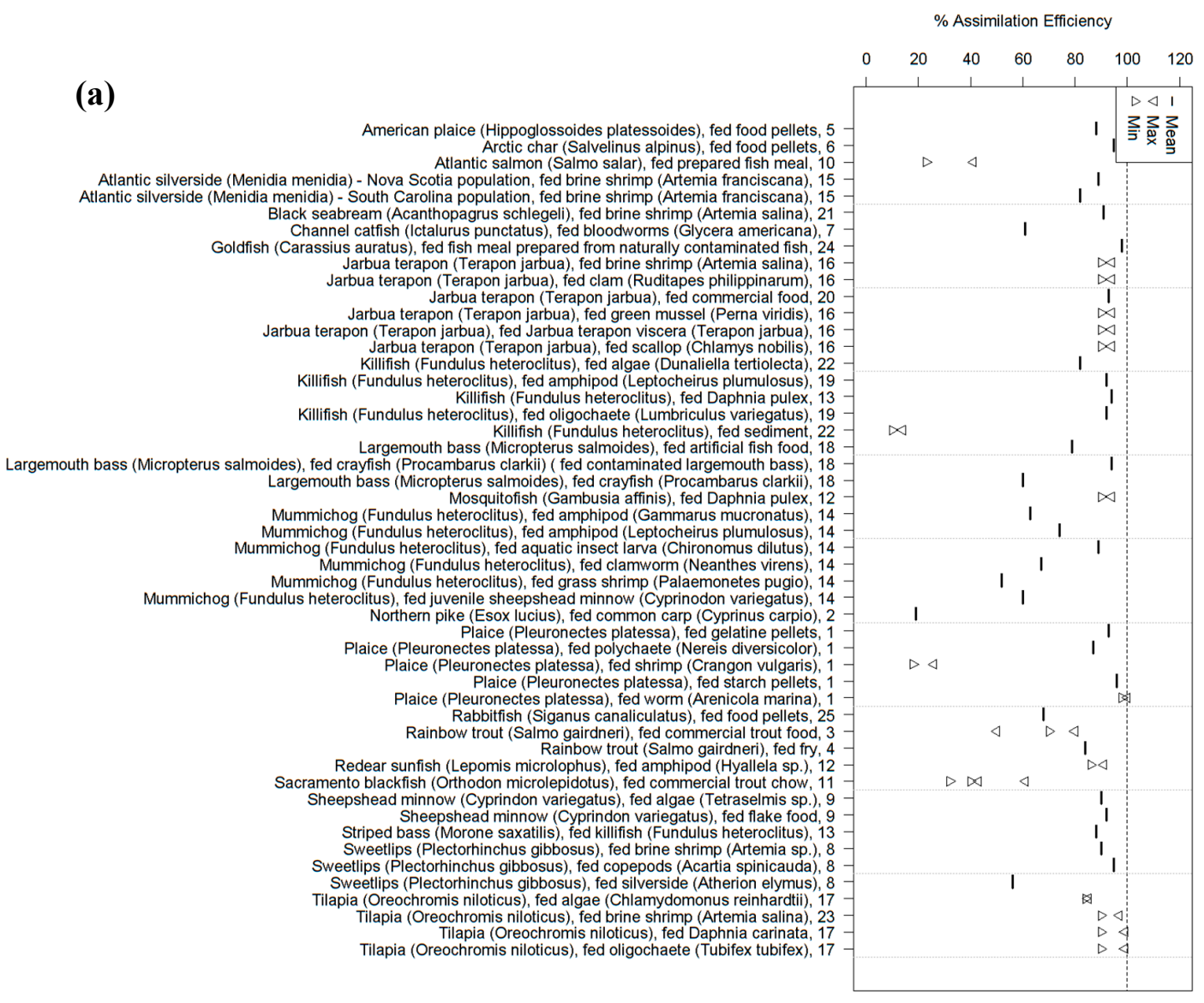

Figure 2. Cont. 


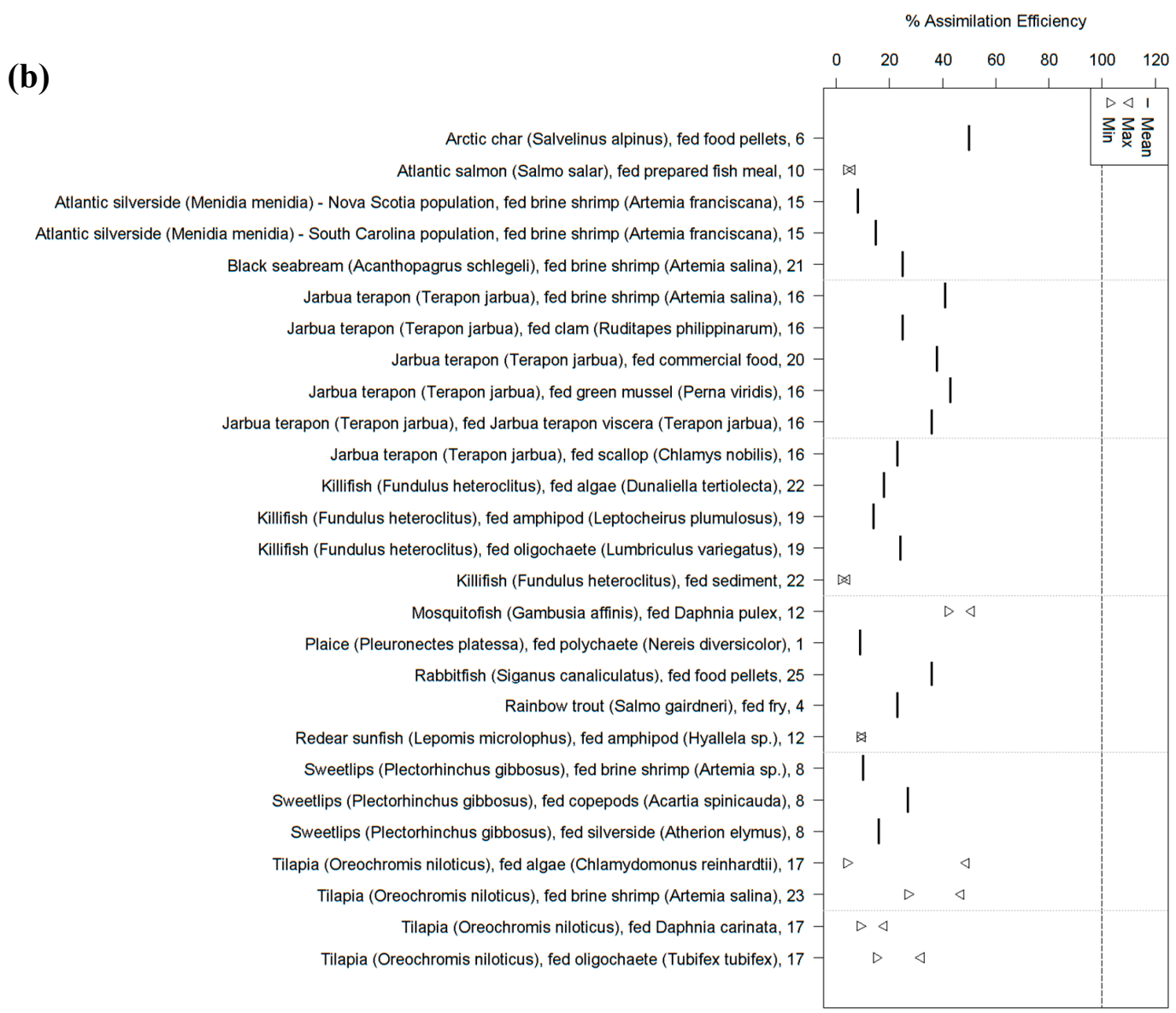

Figure 2. Summary of studies on $\mathrm{AE}$ of $\mathrm{Hg}$ into fish for (a) $\mathrm{MeHg}$ and (b) $\mathrm{Hg}$ (II). In both, each column represents a single species of fish, fed a single type of food. The numbers along the Y-axis indicate studies, as outlined in Table S2.

Following dietary exposure, MeHg quickly accumulates in the gut and then is more slowly transferred to other tissues. For example, in Arctic char (Salvelinus alpinus) exposed to a single dose of ${ }^{203} \mathrm{MeHg}(0.26 \pm 0.05 \mu \mathrm{g} \mathrm{Hg} / \mathrm{g}$ body weight), radioactive $\mathrm{Hg}$ was visualized by autoradiography in the gut tract after one day, and 27 days were required for $95 \%$ of the initial dose to be transferred from the gut to blood [34]. Similarly, intestinal uptake of MeHg took place in sheepshead minnow (Cyprinodon variegatus) within hours of dietary exposure to $\mathrm{MeHg}$ ( 3 or $16 \mu \mathrm{g} / \mathrm{g}$ wet weight), and transfer to other tissues occurred more slowly, as 2 days were required for $95 \%$ of the initial dose to be transferred from intestine to blood [35].

Once in blood, $\mathrm{MeHg}$ associates with red blood cells and binds with hemoglobin due to its relatively high concentrations of sulfhydryl groups as observed in a study of rainbow trout [36]. In contrast to $\mathrm{MeHg}, \mathrm{Hg}$ (II) binds with cysteine, albumin, and glutathione (GSH) in plasma, following absorption into blood. Blood, containing both forms of $\mathrm{Hg}$, moves from the intestinal tract to the liver via the portal vein. Due to its strategic positioning within the circulatory system, the liver is exposed to dietary MeHg and $\mathrm{Hg}$ (II) before other tissues and thus the liver's ability to metabolize or eliminate $\mathrm{Hg}$ may dictate levels in other fish tissues. The $\mathrm{MeHg}$ and $\mathrm{Hg}$ (II) remaining in blood continue to travel through the circulatory system to other parts of the body. The binding of $\mathrm{MeHg}$ with hemoglobin is reversible, thus facilitating $\mathrm{MeHg}$ transfer to other tissues [36]. In Arctic char, the transfer of $\mathrm{MeHg}$ from blood to tissues likely involves an intermediate passage through blood plasma, which has been suggested to be a rate-limiting step due to the low concentrations of small mobile sulfhydryl ligands in plasma [34]. 
Concentrations of $\mathrm{Hg}$ in fish are often highest in well-perfused tissues such as liver, spleen, and kidney [37,38], however muscle represents the largest pool of $\mathrm{Hg}$ in fish. For example, after dietary exposure to ${ }^{203} \mathrm{MeHg}$ and a subsequent 30 -day depuration period, $71 \%-77 \%$ of the accumulated $\mathrm{MeHg}$ was found in the muscle of tilapia (Oreochromis niloticus), with lower percentages found in the head $(16 \%-18 \%)$ and viscera $(5 \%-9 \%)$ [21]. In fish muscle tissue, $>95 \%$ of the $\mathrm{Hg}$ (II) is present as $\mathrm{MeHg}$ [39]. Evidence from X-ray absorption spectroscopy has suggested that in fish muscle, $\mathrm{MeHg}$ is most likely bound to cysteine residues in proteins [40]. This has been substantiated by HPLC-ICP-MS analyses of dogfish muscle showing that $\mathrm{MeHg}$ is predominantly present as MeHgCys [14]. Therefore, $\mathrm{MeHgCys}$ is likely the most relevant form for human exposures as realized through the consumption of contaminated seafood muscle tissue.

Both laboratory and manipulative field studies have demonstrated that fish eliminate $\mathrm{MeHg}$ very slowly [41-43]. For example, Van Walleghen and colleagues [43] monitored $\mathrm{Hg}$ (II) in northern pike, which had naturally accumulated isotope-enriched $\mathrm{MeHg}$ through a whole-lake loading study, after their transfer to a different lake. Spiked $\mathrm{Hg}$ (II) was detected in muscle samples over the course of the 7-year study, and the authors estimated the half-life of $\mathrm{Hg}$ (II) in muscle at 3.3 years. The slow elimination of $\mathrm{MeHg}$ plays a role in the elevated concentrations of $\mathrm{Hg}$ in larger and older fish [38].

The evidence reviewed here suggests that, while the assumption that $\mathrm{MeHg}$ is more efficiently absorbed from the intestine than $\mathrm{Hg}$ (II) generally holds true, the assumption that $\mathrm{MeHg}$ is nearly $100 \%$ absorbed from the diet may not apply in all cases. In particular, the type of food through which fish are exposed to $\mathrm{Hg}$ may affect $\mathrm{AE}$. It is not clear if $\mathrm{Hg}$ assimilation is dependent on concentration or time, though existing evidence suggests this is possible. The efficiency of $\mathrm{MeHg}$ transfer from food to fish, and the slow elimination of MeHg from fish, have consequences for both fish health and human health.

\section{Humans}

Humans are exposed to $\mathrm{Hg}$ primarily as $\mathrm{MeHgCys}$ from fish in the diet. The assumption that $95 \%-100 \%$ of the ingested $\mathrm{MeHg}$ is absorbed into systemic circulation is largely based on limited and outdated studies. One of the earliest studies (published in 1969) involved oral administration of aqueous methylmercuric nitrate to three middle-aged (37-44 years) Caucasian male volunteers [44]. Another early study (published in 1971) with 15 subjects ( 9 male, 6 female, ages 27-48, no indication of race/ethnicity) investigated $\mathrm{Hg}$ bioavailability after oral exposure to fish protein-bound $\mathrm{MeHg}$ [45]. While they are valuable as studies on humans, both suffer from limitations. Conclusions in both studies are drawn from small sample sizes. Both studies focus on acute exposures and do not utilize realistic exposure routes. For example, the studies use a relatively small portion size of ingested fish ( $10 \mathrm{~g}$ vs. the $75 \mathrm{~g}$ serving in Health Canada's food guide [46] and the $85 \mathrm{~g}$ serving by the U.S. Food and Drug Administration (FDA) [47]), and use either aqueous methylmercuric nitrate or fish tissue spiked with methylmercuric nitrate rather than the more physiologically relevant methylmercuric cysteine, methylmercuric chloride, or $\mathrm{MeHg}$ bound to fish muscle tissue from natural contamination.

A body of emerging research suggests that $\mathrm{Hg}$ may be less than $100 \%$ bioavailable from seafood to human consumers. While these studies are beginning to explore these circumstances, there are a number of specific aspects of bioavailability that warrant much more research. As a brief primer relevant to the sections that follow, bioavailability encompasses three primary processes: bioaccessibility, absorption, and metabolism [13]. Bioaccessibility refers to the fraction of an ingested compound that is released from the food matrix into soluble form within the gastrointestinal tract; in vivo bioaccessibility represents a combined contribution of human and bacterial digestion to solubilization. Absorption refers to the movement of the bioaccessible compound into and across the intestinal epithelium to reach the blood supply; some studies break absorption up into two sub-processes: cellular retention (how much $\mathrm{Hg}$ accumulates inside intestinal cells) and cellular transport (how much $\mathrm{Hg}$ accumulates on the basolateral side of cells after introduction of $\mathrm{Hg}$ to the apical side). Metabolism of the compound may occur during both digestion/solubilization and absorption, which may modify the degree of bioavailability of a compound; metabolism also 
includes metabolism that occurs in the liver before the absorbed compound reaches the general circulation. Thus, for example, bioaccessibility can be used as a conservative estimate for bioavailability, as bioaccessibility is a theoretical maximum possible bioavailability [13,48]. Though some studies exist (and are reviewed below), surprisingly little attention has been devoted to MeHg bioavailability from food matrices in humans, though food remains the principal route of $\mathrm{MeHg}$ exposure in the general population.

We identified 20 studies that report on some aspect of bioavailability (either bioaccessibility or absorption) for total Hg, MeHg, or both (Figures 3 and 4; Tables S3 and S5). These studies cover 59 different types of seafood prepared in six different ways (raw, grilled, boiled, fried, steamed, or roasted) and packaged in four different ways (fresh, frozen, canned in water, or canned in oil) (note: numbers below may add up to more than the total number of studies because some studies investigated more than one aspect of bioavailability). Sixteen studies report bioaccessibility from naturally-contaminated fish, and of these fifteen report on total $\mathrm{Hg}$, eight report on $\mathrm{MeHg}$, and seven report on both. Only three of these in vitro studies incorporate absorption and metabolism to investigate the full process of bioavailability; two report on absorption from naturally-contaminated fish (one each reporting on total $\mathrm{Hg}$ and $\mathrm{MeHg}$ ), while one reports bioavailability from a range of lab-prepared standards (reporting on both total $\mathrm{Hg}$ and $\mathrm{MeHg}$ ).

Overall mean bioaccessibility estimates ranged from 2\% to $100 \%$ for $\mathrm{MeHg}$ and $0.2 \%$ to $94 \%$ for total $\mathrm{Hg}$; overall mean absorption estimates ranged from $12 \%$ to $79 \%$ for $\mathrm{MeHg}$ and $49 \%$ to $69 \%$ for total $\mathrm{Hg}$ (Figures 3 and 4; Tables S3 and S5). Some of the studies investigated only a single type of seafood (e.g., Costa et al. [49] only investigated salmon), while others investigated many types of seafood [50-52]. Some studies investigated only a few types of seafood, but also investigated how different ways of cooking these seafoods affected $\mathrm{Hg}$ bioaccessibility relative to raw samples of the same seafood [53,54].

To our knowledge, the three in vitro $\mathrm{Hg}$ bioaccessibility studies that have included the greatest number of seafoods have looked at 20 seafood types in Hong Kong, China [52], 16 seafood types in Valencia, Spain [50], and 10 seafood types in Montreal, Canada [51]. Since the methods used in all studies are broadly similar, examining these three studies may provide some of the clearest comparisons across different types of seafood. Though comparisons among the studies are challenged by methodological differences, at least looking within each study can provide useful comparisons between types of seafood. For example, Calatayud et al. [50] and Siedlikowski et al. [51] use near-identical methods, while Wang et al. [52] use methods that use a lower weight of fish to start the digestion and a longer small intestinal digestion ( $6 \mathrm{~h}$ vs. $2 \mathrm{~h}$ ). In vitro total $\mathrm{Hg}$ bioaccessibility ranged from $21 \%$ to $52 \%$, and $\mathrm{MeHg}$ bioaccessibility ranged from $20 \%$ to $59 \%$ from raw seafood in the Hong Kong study [52]. In vitro total $\mathrm{Hg}$ bioaccessibility from 16 raw seafood species in Spain ranged from $35 \%$ to $106 \%$; cellular retention and transport (components of absorption, itself a component of bioavailability) after $2 \mathrm{~h}$ of incubation with cultured Caco-2 cells was $49 \%-69 \%$ and $3 \%-14 \%$, respectively, in swordfish, the only seafood assayed for absorption [50]. In vitro MeHg bioaccessibility from 10 raw seafood species in Montreal ranged from $50 \%$ to $100 \%$; absorption after $2 \mathrm{~h}$ of incubation with cultured Caco-2 cells ranged from $29 \%$ to $67 \%$ of the initial undigested sample [51]. Taken together, these three studies document substantial variability in $\mathrm{Hg}$ bioavailability from seafood, and also challenge the assumption that $95 \%-100 \%$ of ingested $\mathrm{MeHg}$ is absorbed. 
(a)

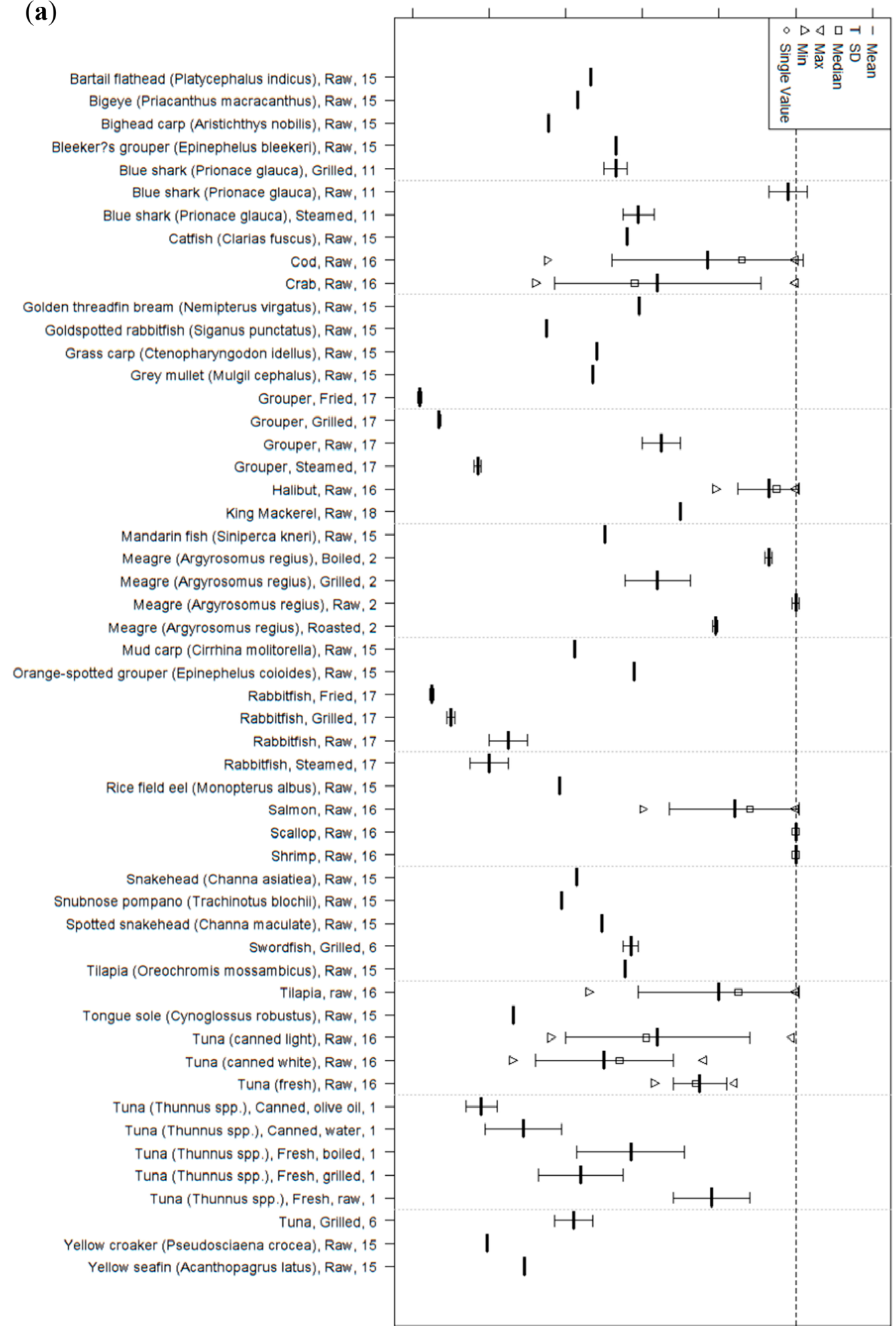

Figure 3. Cont. 


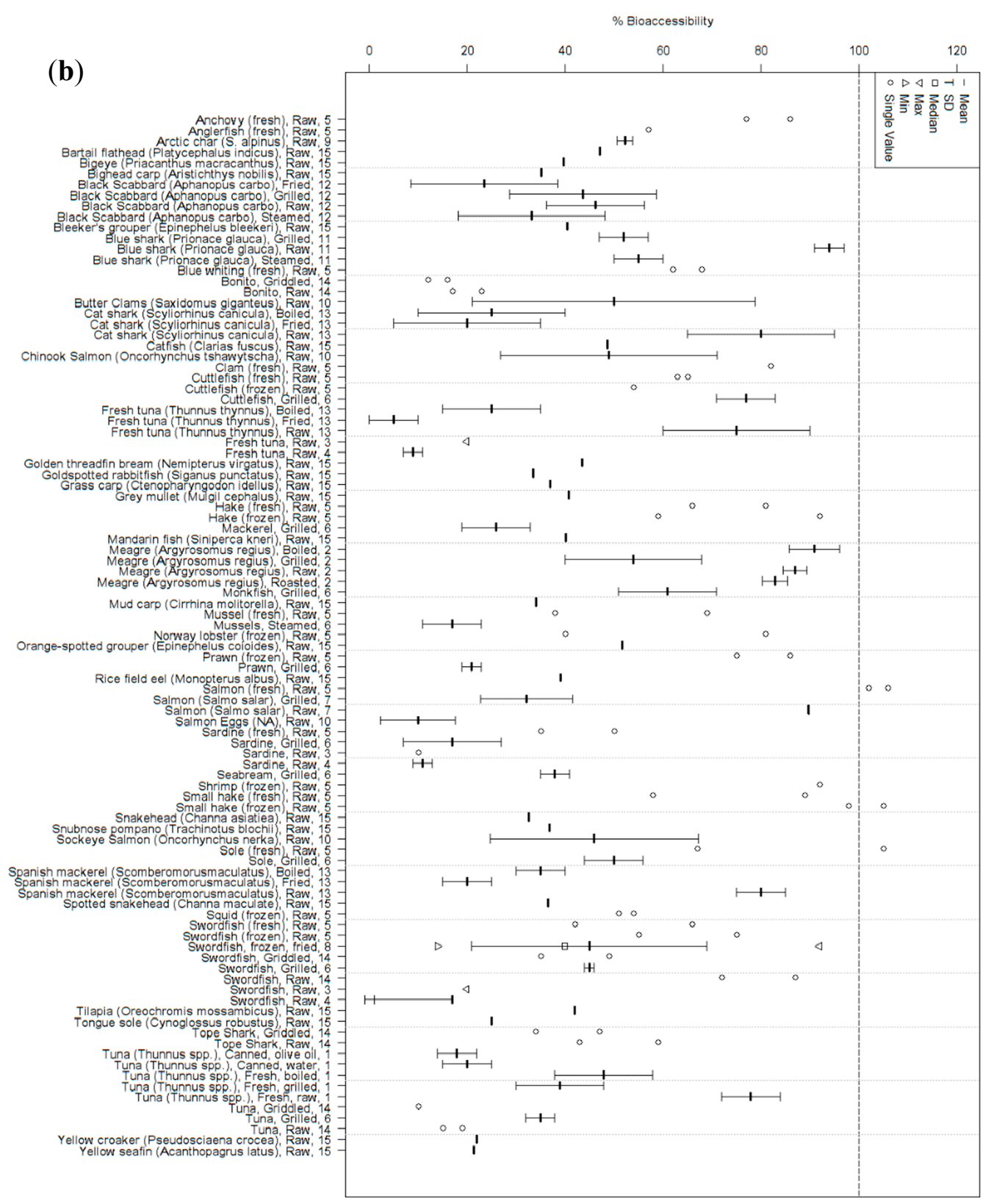

Figure 3. Summary of in vitro studies on bioaccessibility of $\mathrm{Hg}$ to humans from fish consumption for (a) $\mathrm{MeHg}$ and (b) total $\mathrm{Hg}$. In both, each column represents a single species of fish, prepared and/or packaged in a particular way. The numbers along the Y-axis indicate studies, as outlined in Table S4. 
(a)

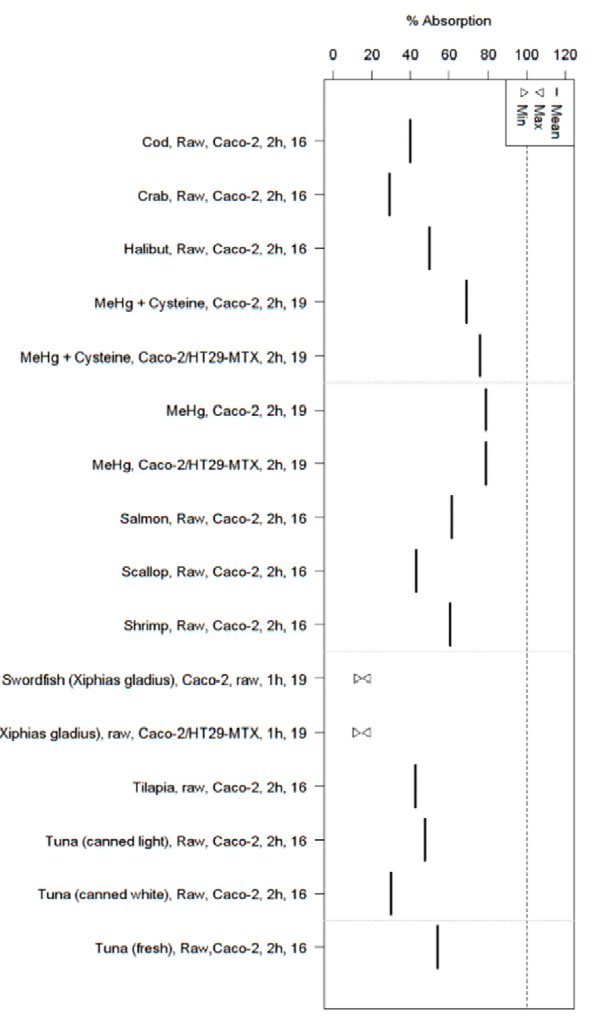

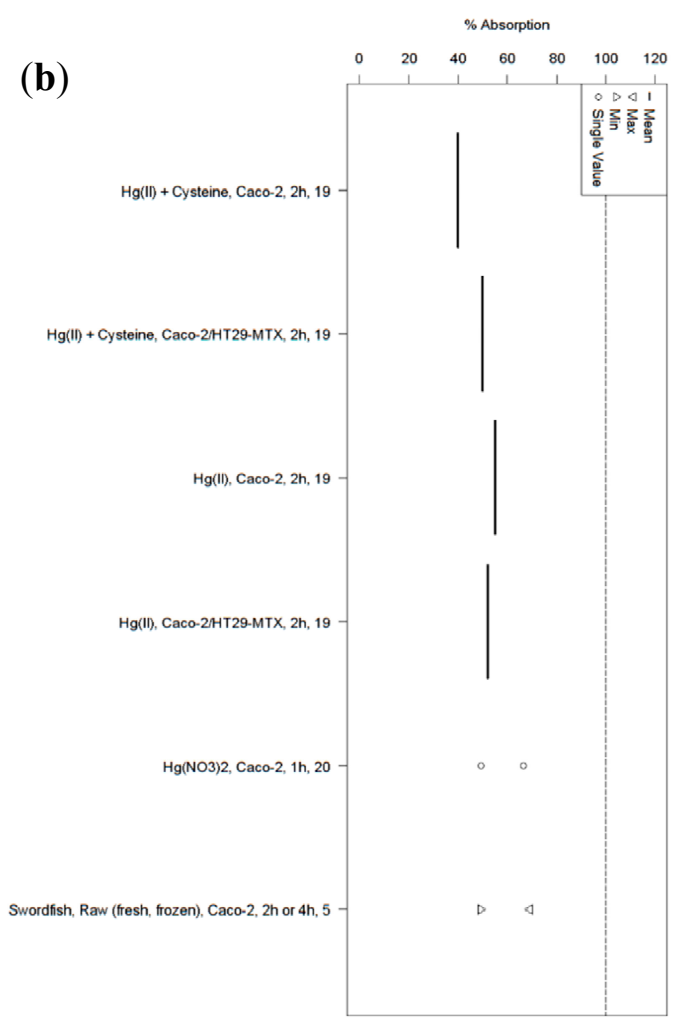

Figure 4. Summary of in vitro studies on absorption of $\mathrm{Hg}$ to human intestinal cells from fish consumption for (a) $\mathrm{MeHg}$ and (b) total $\mathrm{Hg}$. In both, each column represents a single species of fish, prepared and/or packaged in a particular way, and introduced to either a monoculture of Caco-2 (intestinal epithelial-like cells) or a co-culture of Caco-2 and HT29-MTX (mucin-producing cells analogous to goblet cells). The numbers along the Y-axis indicate studies, as outlined in Table S4.

Various cooking methods have been investigated for effects on $\mathrm{Hg}$ concentration in seafood edible tissues, and to a lesser degree bioaccessibility (Table 1). In general, cooking tends to increase the wet weight concentration of $\mathrm{Hg}$ in seafood, though this is almost certainly due to loss of moisture during cooking rather than any change in the amount of $\mathrm{Hg}$ in the seafood itself. Cooking also tends to decrease bioaccessibility of $\mathrm{Hg}$ from seafood, relative to raw seafood, with the more "intense" the cooking process the less bioaccessible the $\mathrm{Hg}$ after cooking (i.e., cooking treatments in order of most to least bioaccessible would be raw $>$ steamed / boiled $>$ grilled $>$ fried). Total $\mathrm{Hg}$ bioaccessibility in boiled and fried fish were $40 \%$ and $60 \%$ lower, respectively, than raw samples of the same fish among samples of Spanish mackerel (Scomberomorus maculatus), cat shark (Scyliorhinus sp.) and red tuna (Thunnus thynnus) [54]; MeHg bioaccessibility was reduced by $75 \%-96 \%$ for grouper (Epinephelus coioides) and 29\%-77\% for rabbitfish (Siganus oramin) when steamed, grilled, or fried, compared to raw [53]. These studies concerning MeHg bioaccessibility demonstrate that cooking has an affect though most of the MeHg bioaccessibility studies have simply used raw seafood. Beyond bioaccessibility, to our knowledge no studies have investigated $\mathrm{MeHg}$ bioavailability from fish after different cooking methods. 
Table 1. Effect of cooking or preparation treatment on $\mathrm{Hg}$ concentration, bioaccessibility, and bioavailability. Effects of cooking treatment expressed relative to raw fish; effects of skinning and trimming fat expressed relative to unskinned, untrimmed fish.

\begin{tabular}{|c|c|c|c|c|c|}
\hline Fish Species & Cooking Treatment & Hg Concentration Effect & Weight Measurement & Hg Bioaccessibility Effect & Reference \\
\hline \multirow{3}{*}{ Meagre (farmed; Argyrosomus regius) } & Grilled & $\begin{array}{l}\text { increased total } \mathrm{Hg} \mathrm{33 \%} \text {; } \\
\text { increased } \mathrm{MeHg} 25 \%\end{array}$ & unclear; probably wet weight & Not studied & \multirow{3}{*}{ [55] } \\
\hline & Boiled & no change & unclear; probably wet weight & Not studied & \\
\hline & Roasted & $\begin{array}{l}\text { increased total Hg 19\%; } \\
\text { increased MeHg } 19 \%\end{array}$ & unclear; probably wet weight & Not studied & \\
\hline \multirow{2}{*}{$\begin{array}{l}\text { Largemouth bass } \\
\text { (Micropterus salmoides) }\end{array}$} & $\begin{array}{l}\text { Deep fried (with } \\
\text { breading) }\end{array}$ & increased total $\mathrm{Hg} 45 \%$ & wet weight & Not studied & \multirow{2}{*}{ [56] } \\
\hline & $\begin{array}{l}\text { Deep fried (without } \\
\text { breading) }\end{array}$ & increased total $\mathrm{Hg} 75 \%$ & wet weight & Not studied & \\
\hline \multirow{2}{*}{$\begin{array}{l}\text { Spanish mackerel (Scomberomorus macalatus), } \\
\text { cat shark (Scyliorhinus sp.), red tuna } \\
\text { (Thunnus thynnus) }\end{array}$} & Fried & no change & dry weight & $\begin{array}{l}\text { total Hg: } 65 \% \text { lower; } \mathrm{MeHg}: \\
85 \% \text { lower } \\
\end{array}$ & \multirow{2}{*}{ [54] } \\
\hline & Boiled & no change & dry weight & $\begin{array}{l}\text { total } \mathrm{Hg}: 38 \% \text { lower; } \mathrm{MeHg}: \\
54 \% \text { lower }\end{array}$ & \\
\hline \multirow{2}{*}{$\begin{array}{l}\text { Fresh swordfish (Xiphias gladius), frozen tope } \\
\text { shark (Galeorhinus galeus), frozen bonito } \\
\text { (Sarda sp.), fresh tuna (Thunnus sp.) }\end{array}$} & Hot plate/griddle & $\begin{array}{l}\text { total Hg increased: swordfish } \\
(43 \%) \text {, tuna }(32 \%) \text {, tope shark } \\
(22 \%) \text {, bonito }(20 \%)\end{array}$ & wet weight & $\begin{array}{l}\text { total } \mathrm{Hg} \text { in raw fish: } 42 \% \\
(13 \%-87 \%) ; \text { total } \mathrm{Hg} \text { in cooked } \\
\text { fish: } 26 \%(6 \%-49 \%)\end{array}$ & \multirow[t]{2}{*}{ [57] } \\
\hline & Hot plate/griddle & no change & dry weight & Not studied & \\
\hline Sardine, hake, tuna & $\begin{array}{l}\text { Fried } \\
\text { Grilled }\end{array}$ & $\begin{array}{l}\text { no change } \\
\text { no change }\end{array}$ & $\begin{array}{l}\text { wet weight } \\
\text { wet weight }\end{array}$ & $\begin{array}{l}\text { Not studied } \\
\text { Not studied }\end{array}$ & \multirow{2}{*}{ [58] } \\
\hline Hake & $\begin{array}{c}\text { Roasted } \\
\text { Boiled }\end{array}$ & $\begin{array}{l}\text { no change } \\
\text { no change }\end{array}$ & $\begin{array}{l}\text { wet weight } \\
\text { wet weight }\end{array}$ & $\begin{array}{l}\text { Not studied } \\
\text { Not studied }\end{array}$ & \\
\hline Striped bass & $\begin{array}{c}\text { Baked } \\
\text { Broiled } \\
\text { Fried } \\
\text { Microwaved } \\
\text { Poached } \\
\text { Steamed }\end{array}$ & $\begin{array}{l}\text { no change } \\
\text { no change } \\
\text { no change } \\
\text { no change } \\
\text { no change } \\
\text { no change }\end{array}$ & $\begin{array}{l}\text { dry weight } \\
\text { dry weight } \\
\text { dry weight } \\
\text { dry weight } \\
\text { dry weight } \\
\text { dry weight }\end{array}$ & $\begin{array}{l}\text { Not studied } \\
\text { Not studied } \\
\text { Not studied } \\
\text { Not studied } \\
\text { Not studied } \\
\text { Not studied }\end{array}$ & [59] \\
\hline Brown trout (Salmo trutta) & Skinned, trimmed fat & $\begin{array}{c}\text { increased total } \mathrm{Hg} 25 \% \\
\text { (male fish), 32\% (female fish) }\end{array}$ & dry weight & Not studied & {$[60]$} \\
\hline
\end{tabular}


Tuna has been estimated to be amongst the most relevant $\mathrm{Hg}$ sources worldwide [61-65]. Of particular note in more recent studies is that $\mathrm{Hg}$ from canned tuna may be less bioaccessible than $\mathrm{Hg}$ from raw tuna [51,66]. Afonso et al. [66] proposed that the reduction in bioaccessible $\mathrm{Hg}$ in canned seafood may be a result of denatured proteins becoming less accessible to the protease action and consequently less $\mathrm{Hg}$ is solubilized during digestion. The strong affinity of $\mathrm{Hg}$ for proteins [67] and the ability of protein denaturation by heat to modify the reactivity of protein-bound $\mathrm{Hg}$ [68] suggest it is possible that the heating involved in the canning process, similar to what is seen for various methods of cooking fish, reduces bioaccessibility of $\mathrm{Hg}$ from fish.

Some nutrients and foods appear to be able to modify $\mathrm{Hg}$ bioaccessibility. Nutrients and foods investigated for interactions with $\mathrm{MeHg}$ were reviewed by Chapman and Chan [69]. Examples of more recent studies on interactions between food components and $\mathrm{MeHg}$ from seafood are presented in Table 2. A number of notable items, including tea, coffee [54,70], and various forms of fiber (wheat bran, OAT bran, and psyllium [70]) have been associated with reducing Hg bioaccessibility in vitro. Epidemiological evidence in support is minimal, but represents a fruitful area of future research. For example, a 12-month prospective dietary assessment of 26 adult women in the Brazilian Amazon showed that those who ate more tropical fruits had lower levels of $\mathrm{Hg}$ in hair than those who did not, for a given number of fish meals [71]; while the researchers suggest that "absorption" (i.e., bioavailability) may be one possible mechanism explaining the finding, an in vitro study showed no effect of grapefruit juice on bioaccessibility of $\mathrm{Hg}[70]$.

Table 2. Recent examples of nutrients/foods with effects on gut-relevant transport of $\mathrm{MeHg}$.

\begin{tabular}{|c|c|c|c|c|}
\hline Food or Nutrient & $\mathrm{Hg}$ Exposure & Model & Description of Interaction & Reference \\
\hline Tea, coffee & $\begin{array}{c}\text { 1-4 } \mu \mathrm{g} / \mathrm{g} \text { dry weight } \\
\mathrm{Hg} \text { in fish (tuna, } \\
\text { shark, mackerel) }\end{array}$ & $\begin{array}{c}\text { in vitro } \\
\text { digestion—bioaccessibility }\end{array}$ & $\begin{array}{c}\text { Tea and coffee reduced total } \\
\text { Hg bioaccessibility } 10 \%-60 \% \text {, } \\
\text { depending on species }\end{array}$ & \multirow{2}{*}{ [54] } \\
\hline Corn starch & $\begin{array}{c}\text { 1-4 } \mu \mathrm{g} / \mathrm{g} \text { dry weight } \\
\mathrm{Hg} \text { in fish (tuna, } \\
\text { shark, mackerel) }\end{array}$ & $\begin{array}{c}\text { in vitro } \\
\text { digestion—bioaccessibility }\end{array}$ & $\begin{array}{l}\text { Corn starch reduced total } \mathrm{Hg} \\
\text { bioaccessibility by } 20 \% \\
\text { (tuna only) }\end{array}$ & \\
\hline Tropical Fruits & $\mathrm{Hg}$ in fish meals & Human, prospective study & $\begin{array}{l}\text { Consumption of } 1 \text { fruit/day } \\
\text { was associated with lower hair } \\
\mathrm{Hg} \text { than consumption of } \\
<1 \text { fruit/day }\end{array}$ & [71] \\
\hline Green tea extract & fish tissue & $\begin{array}{c}\text { in vitro } \\
\text { digestion—bioaccessibility }\end{array}$ & $\begin{array}{c}\text { reduced } \mathrm{Hg} \text { bioaccessibility } \\
\text { by } 82 \%-92 \%\end{array}$ & \multirow{7}{*}{ [70] } \\
\hline Black tea extract & fish tissue & $\begin{array}{c}\text { in vitro } \\
\text { digestion-bioaccessibility }\end{array}$ & $\begin{array}{c}\text { reduced } \mathrm{Hg} \text { bioaccessibility } \\
\text { by } 88 \%-91 \%\end{array}$ & \\
\hline Soy protein & fish tissue & $\begin{array}{c}\text { in vitro } \\
\text { digestion—bioaccessibility }\end{array}$ & $\begin{array}{c}\text { reduced } \mathrm{Hg} \text { bioaccessibility } \\
\text { by } 44 \%-87 \%\end{array}$ & \\
\hline Grapefruit juice & fish tissue & $\begin{array}{c}\text { in vitro } \\
\text { digestion—-bioaccessibility }\end{array}$ & $\begin{array}{c}\text { no reduction of } \\
\text { bioaccessible } \mathrm{Hg}\end{array}$ & \\
\hline Wheat bran & fish tissue & $\begin{array}{c}\text { in vitro } \\
\text { digestion-bioaccessibility }\end{array}$ & $\begin{array}{l}\text { reduced } \mathrm{Hg} \text { bioaccessibility } \\
\text { by } 84 \%\end{array}$ & \\
\hline OAT bran & fish tissue & $\begin{array}{c}\text { in vitro } \\
\text { digestion-bioaccessibility }\end{array}$ & $\begin{array}{c}\text { reduced } \mathrm{Hg} \text { bioaccessibility } \\
\text { by } 59 \%-85 \%\end{array}$ & \\
\hline Psyllium & fish tissue & $\begin{array}{c}\text { in vitro } \\
\text { digestion—bioaccessibility }\end{array}$ & $\begin{array}{l}\text { reduced } \mathrm{Hg} \text { bioaccessibility } \\
\text { by } 15 \%-31 \%\end{array}$ & \\
\hline
\end{tabular}

Conflicting reports exist on associations between edible seafood tissue total $\mathrm{Hg}$ concentration and $\mathrm{Hg}$ bioavailability to humans. Some studies find that in vitro $\mathrm{Hg}$ bioaccessibility is independent of total $\mathrm{Hg}$ concentration $[51,53,72,73]$, while others indicate a negative correlation between $\mathrm{Hg}$ concentration and bioaccessibility [51,73]. Both studies by Laird et al. [72,73] use the Simulated Human Intestinal Microbial Ecosystem (SHIME), one of the more complex and likely realistic models for assessing human bioaccessibility as it includes the colonic microbiota and represents a fed state. He and Wang [53] 
and Siedlikowski et al. [51] use simpler digestion models that represent a fasted state. Two studies have found a negative correlation between $\mathrm{Hg}$ concentration and cellular absorption [51,74]. Many studies that have reported on bioavailability have not explicitly investigated the relationship between concentration and bioavailability. Thus, it is not clear if $\mathrm{MeHg}$ concentration in edible seafood tissue may be a good proxy for MeHg bioavailability.

The emerging in vitro evidence reviewed here challenges the long-held assumption that nearly $100 \%$ of ingested $\mathrm{Hg}$ is absorbed into the human body by showing cases in which this assumption may not hold (i.e., cases in which bioavailability may be substantially $<100 \%$ ) and by highlighting limitations of some of the studies on which this assumption was based (e.g., studies using an exposure method other than naturally-contaminated fish). As discussed above for fish, it is not clear if the concentration of $\mathrm{Hg}$ is related to its bioavailability, though it may be.

\section{Conclusions}

There is a growing awareness that not all $\mathrm{Hg}$ from the diet is absorbed in both fish and in humans. The purpose of this review paper was to discuss the available state of knowledge concerning the assimilation or bioavailability of MeHg in fish and humans. In doing so, the outcome of this activity shows in a variety of organisms, experimental models, and cases that $\mathrm{Hg}$ bioavailability and assimilation is less than $100 \%$. Specifically, 25 studies on fish were reviewed with AEs for $\mathrm{MeHg}$ ranging between $10 \%$ and $100 \%$ and for $\mathrm{Hg}$ (II) were $2 \%-51 \%$. For humans, 20 studies were reviewed with bioaccessibility estimates ranging from $\sim 2 \%$ to $100 \%$ for $\mathrm{MeHg}$ and $0.2 \%-94 \%$ for $\mathrm{Hg}(\mathrm{II})$; overall mean absorption estimates ranged from $12 \%$ to $79 \%$ for $\mathrm{MeHg}$ and $49 \%-69 \%$ for $\mathrm{Hg}$ (II) and are consistently less than $100 \%$. The summaries presented here challenge a widely-held assumption in the $\mathrm{Hg}$ risk assessment field. Without being able to properly account for the true nature of $\mathrm{Hg}$ bioavailability and assimilation in humans and fish there will be inherent biases in assuming that the proportion of ingested $\mathrm{Hg}$ estimated to reach systemic circulation is 95 to $100 \%$. Moving forward, there are several established model systems, simple to complex, available to characterize $\mathrm{Hg}$ bioavailability and assimilation, and when coupled with more sophisticated analytical approaches such as $\mathrm{Hg}$ stable isotopes, radiotracers, and speciation, the scientific community will be able to deepen our understanding of how the organism "handles" Hg; however, there is not yet an established validation method for bioavailability studies. Such knowledge is needed given that $\mathrm{Hg}$ remains a global contaminant of concern.

Despite growing interest on the topic there remain methodological and conceptual limitations that warrant discussion. Here we discuss some of the main limitations identified based on our review of the literature.

One challenge particular to this review is that most of the studies conducted thus far in fish have been conducted in vivo, while most of the studies focusing on humans have been conducted in vitro, and this makes it difficult to compare findings across the species. In addition, there has been a surge of recent interest in in vitro to in vivo extrapolations [75] which may prove fruitful in terms of better understanding the in vitro bioaccessibility and bioavailability studies. Despite significant mammalian research into $\mathrm{Hg}$ toxicity, mammalian research on $\mathrm{Hg}$ bioavailability is limited. In addition to there being relatively few mammalian studies on bioavailability, many of these studies do not provide clear percent values for bioavailability, but rather point to factors (e.g., dietary factors) that may increase or decrease bioavailability. As such, the majority of data comes from in vitro studies, while animal studies (and a limited number of human studies) provide context. For example, lower bioavailability from food sources artificially-spiked with $\mathrm{Hg}$ than from naturally-contaminated food sources has been demonstrated in both rats [76] and fish [33]. This difference deserves further consideration in discrepancies in reported $\mathrm{Hg}$ bioavailability between human in vivo studies $[44,45]$ and the human-focused in vitro models that are the focus here. There are some additional challenges when it comes to studying bioavailability in humans that are not faced (or not nearly as prominent) in animal studies. In particular, studying bioaccessibility requires direct access to gastrointestinal 
fluids which requires invasive procedures. The ethics of treating humans in vivo with $\mathrm{Hg}$ clearly prevent such studies from being done today, and instead we rely on information from limited and outdated human in vivo studies. Though, with advancements in $\mathrm{Hg}$ exposure science it may be possible to conduct detailed epidemiological surveys and when coupled with sophisticated biomarker analyses (e.g., see Sherman et al. [77]) there may be creative avenues to better resolve Hg bioavailability in populations.

Our models need to better understand what percentage of the ingested $\mathrm{Hg}$ reaches systemic circulation, and thus need more data on bioavailability. However, the vast majority of existing human-focused studies use in vitro models of bioaccessibility to estimate bioavailability. Bioaccessibility is a component of bioavailability, and has been proposed as a conservative estimate of bioavailability (effectively assuming $100 \%$ absorption and no metabolism; $[13,48]$ ). While conservative estimates are generally encouraged in public health contexts, when the exposure is coupled with significant health benefits associated with seafood consumption, overly conservative estimates of exposure may inadvertently harm public health.

Addressing the lack of in vitro/in vivo correlation in existing studies is key to demonstrating which in vitro methods best correspond to in vivo conditions. Some efforts have been made to compare extrapolated human population $\mathrm{Hg}$ exposure (based on measures of fish consumption and in vitro bioaccessibility studies) to estimates of "acceptable" exposure such as the Tolerable Daily Intake [57]. However, to our knowledge only one study [51] has attempted to integrate bioavailability data into a $\mathrm{Hg}$ exposure assessment study to see if this information could better improve the relationship between biomarkers of $\mathrm{Hg}$ (blood and hair) and fish consumption data. In this study, whether accounting for bioaccessibility alone or for bioaccessibility and absorption together, the ability to predict either $\mathrm{Hg}$ biomarker levels from survey-based fish consumption information did not improve [51]. There are several possible reasons for this: (1) concentrations of $\mathrm{Hg}$ in fish tissue were estimated for each type of fish from a FDA database rather than directly measured in subsamples of the fish that subjects from the cohort had actually eaten; (2) the uncertainty inherent in food frequency questionnaires which were used to collect the fish consumption data; and (3) the in vitro bioavailability portion of the study was only able to include the top 10 most-consumed fish, leaving a number of other fish for which bioavailability had to be assumed to be $100 \%$ (these "leftover" fish included some less-popularly consumed fish that have high $\mathrm{Hg}$ concentrations that may contribute a substantial portion of the exposure for the smaller number of individuals who consume them). Nonetheless, more studies are needed that consider bioavailability data in exposure assessments.

Another key challenge is a lack of standardized methods between different studies for assessing bioaccessibility in vitro; different studies use different enzyme concentrations, digestion lengths, and separation methods (for example, as reviewed in Hur et al. [78]). Notably, the choice of separation method has been demonstrated to influence the ultimate assessment of bioaccessibility from soil of a variety of metals, including $\mathrm{Hg}$ [79]. It is not yet known if such differences also apply for $\mathrm{MeHg}$ from seafood. For example, of the studies we reviewed 7 studies looked at 2 types of tuna, including Atlantic bluefin tuna (Thunnus thynnus) and unspecified tuna species (Thunnus spp.). In bluefin tuna, $\mathrm{Hg}(\mathrm{II})$ was $75 \%$ bioaccessible when raw, but when cooked it dropped to $5 \%$ (fried) and $25 \%$ (boiled). In unspecified tuna species, $\mathrm{Hg}$ (II) bioaccessibility ranged from $9 \%-78 \%$ (raw), 6\%-39\% (grilled), and was $48 \%$ (boiled), $18 \%$ (canned in olive oil), and 20\% (canned in water) (Figure S1). MeHg bioaccessibility was not assessed for bluefin tuna, but for unspecified tuna it was $63 \%-84 \%$ (raw), $42 \%-44 \%$ (grilled), $57 \%$ (boiled), $18 \%$ (canned in olive oil), $29 \%$ (canned in water), $36 \%-99 \%$ (canned light), and $26 \%-76 \%$ (canned white) (Figure S2). Without a standardized method, it is difficult to determine whether this wide range of bioaccessibility reported for tuna is due to methodological differences, differences in location and source of the fish, species difference of the fish, or other factors.

Beyond the methodological aspects above, there is growing awareness of factors (e.g., nutrition, gut microbiome, and genetics) that may also contribute to variability in $\mathrm{Hg}$ bioavailability. Other nutritional factors that can influence $\mathrm{Hg}$ bioavailability are outlined in Table 2. The gut 
microbiome is implicated in bioavailability of $\mathrm{Hg}$ in rats [80], mice [81], and in vitro models [72], and given the great interest in the microbiome we anticipate seeing this incorporated into $\mathrm{Hg}$ bioavailability studies. The contribution of genetic variation to risk from $\mathrm{Hg}$ exposure has been reviewed elsewhere; of note for bioavailability, specific genetic polymorphisms in pathways such as the OAT, glutathione metabolism, metallothioneins, and selenoproteins, have already been associated with either higher or lower biomarker levels of $\mathrm{MeHg}$ or inorganic $\mathrm{Hg}$ [82].

In summary, for both fish and humans, a number of factors (e.g., Hg source, cooking methods, nutrients) are shown to affect $\mathrm{Hg}$ bioavailability. The summaries presented here challenge a widely-held assumption in the $\mathrm{Hg}$ risk assessment field, and along with further improvements in methodology for evaluating bioavailability, show potential to inform a more nuanced understanding of the risks due to $\mathrm{Hg}$ from consumption of various types of fish under certain conditions.

Supplementary Materials: The following are available online at www.mdpi.com/1660-4601/14/2/169/s1, Figure S1: Case study of $\mathrm{MeHg}$ bioaccessibility from tuna, Figure S2: Case study of $\mathrm{Hg}$ (II) bioaccessibility from tuna, Table S1: MeHg and $\mathrm{Hg}$ (II) assimilation efficiency for various fish species, Table S2: Key for studies for Figure 2, Table S3: Bioaccessibility of $\mathrm{MeHg}$ and $\mathrm{Hg}$ (II) to humans from various fish, Table S4: Key for studies for Figures 3 and 4, Table S5: Absorption of $\mathrm{MeHg}$ and $\mathrm{Hg}$ (II) to humans from various fish.

Acknowledgments: The authors acknowledge support from the Natural Sciences and Engineering Research Council of Canada (NSERC), Canada Research Chairs (CRC) Program, the Northern Contaminants Program (NCP), and McGill University.

Author Contributions: Mark A. Bradley, Benjamin D. Barst, and Niladri Basu each contributed to the conception of the work, the review and interpretation of publications used in the work, the drafting and critical revision of the work, and gave final approval to the version to be published. All authors agree to be accountable for the accuracy and integrity of the work.

Conflicts of Interest: The authors declare no conflict of interest.

\section{References}

1. Ha, E.; Basu, N.; Bose-O'Reilly, S.; Dorea, J.G.; McSorley, E.; Sakamoto, M.; Chan, H.M. Current progress on understanding the impact of mercury on human health. Environ. Res. 2016, 152, 419-433. [CrossRef] [PubMed]

2. Scheuhammer, A.M.; Basu, N.; Evers, D.C.; Heinz, G.H.; Sandheinrich, M.; Bank, M.S. Toxicology of mercury in fish and wildlife: Recent advances. In Mercury in the Environment: Pattern and Process; Bank, M.S., Ed.; University of California Press: Berkeley, CA, USA, 2012.

3. Grandjean, P.; Weihe, P.; Jørgensen, P.; Clarkson, T.; Cernichiari, E.; Viderø, T. Impact of maternal seafood diet on fetal exposure to mercury, selenium, and lead. Arch. Environ. Health Int. J. 1992, 47, 185-195. [CrossRef] [PubMed]

4. Julshamn, K.; Andersen, A.; Ringdal, O.; Mørkøre, J. Trace elements intake in the Faroe Islands I. Element levels in edible parts of pilot whales (Globicephalus meleanus). Sci. Total Environ. 1987, 65, 53-62. [CrossRef]

5. Zhang, H.; Feng, X.; Larssen, T.; Qiu, G.; Vogt, R.D. In inland China, rice, rather than fish, is the major pathway for methylmercury exposure. Environ. Health Perspect. 2010, 118, 1183-1188. [CrossRef] [PubMed]

6. Mergler, D.; Anderson, H.A.; Chan, L.H.M.; Mahaffey, K.R.; Murray, M.; Sakamoto, M.; Stern, A.H. Methylmercury exposure and health effects in humans: A worldwide concern. J. Hum. Environ. 2007, 36, 3-11. [CrossRef]

7. Sheehan, M.C.; Burke, T.A.; Navas-Acien, A.; Breysse, P.N.; McGready, J.; Fox, M.A. Global methylmercury exposure from seafood consumption and risk of developmental neurotoxicity: A systematic review. Bull. World Health Organ. 2014, 92, 254-269. [CrossRef] [PubMed]

8. Karagas, M.R.; Choi, A.L.; Oken, E.; Horvat, M.; Schoeny, R.; Kamai, E.; Cowell, W.; Grandjean, P.; Korrick, S. Evidence on the human health effects of low-level methylmercury exposure. Environ. Health Perspect. 2012, 120, 799-806. [CrossRef]

9. Mozaffarian, D.; Rimm, E.B. Fish intake, contaminants, and human health: Evaluating the risks and the benefits. JAMA 2006, 296, 1885-1899. [CrossRef] [PubMed]

10. Swain, E.B.; Jakus, P.M.; Rice, G.; Lupi, F.; Maxson, P.A.; Pacyna, J.M.; Penn, A.; Spiegel, S.J.; Veiga, M.M. Socioeconomic consequences of mercury use and pollution. J. Hum. Environ. 2007, 36, 45-61. [CrossRef] 
11. Mahaffey, K.R.; Rice, G.E.; Swartout, J. Mercury Study Report to Congress Volume IV: An Assessment of Exposure to Mercury in the United States. Available online: http://www.epa.gov/mercury/report.htm (accessed on 29 November 2016).

12. Di Giulio, R.T.; Hinton, D.E. The Toxicology of Fishes; CRC Press: Boca Raton, FL, USA, 2008.

13. Versantvoort, C.H.M.; van de Kamp, E.; Rompelberg, C.J.M. Development and Applicability of an In Vitro Digestion Model in Assessing the Bioaccessibility of Contaminants from Food. Available online: http://rivm.openrepository.com/rivm/bitstream/10029/18885/10021/320102002.pdf (accessed on 29 November 2016).

14. Lemes, M.; Wang, F. Methylmercury speciation in fish muscle by HPLC-ICP-MS following enzymatic hydrolysis. J. Anal. At. Spectrom. 2009, 24, 663-668. [CrossRef]

15. Leaner, J.J.; Mason, R.P. Methylmercury accumulation and fluxes across the intestine of channel catfish, Ictalurus punctatus. Comp. Biochem. Physiol. C Toxicol. Pharmacol. 2002, 132, 247-259. [CrossRef]

16. Hoyle, I.; Handy, R. Dose-dependent inorganic mercury absorption by isolated perfused intestine of rainbow trout, Oncorhynchus mykiss, involves both amiloride-sensitive and energy-dependent pathways. Aquat. Toxicol. 2005, 72, 147-159. [CrossRef] [PubMed]

17. Pärt, P.; Lock, R. Diffusion of calcium, cadmium and mercury in a mucous solution from rainbow trout. Comp. Biochem. Physiol. C Comp. Pharmacol. 1983, 76, 259-263. [CrossRef]

18. Bridges, C.C.; Zalups, R.K. Transport of inorganic mercury and methylmercury in target tissues and organs. J. Toxicol. Environ. Health 2010, 13, 385-410. [CrossRef] [PubMed]

19. Hall, B.; Bodaly, R.; Fudge, R.; Rudd, J.; Rosenberg, D. Food as the dominant pathway of methylmercury uptake by fish. Water, Air Soil Pollut. 1997, 100, 13-24.

20. Hrenchuk, L.E.; Blanchfield, P.J.; Paterson, M.J.; Hintelmann, H.H. Dietary and waterborne mercury accumulation by yellow perch: A field experiment. Environ. Sci. Technol. 2011, 46, 509-516. [CrossRef] [PubMed]

21. Wang, R.; Wong, M.-H.; Wang, W.-X. Mercury exposure in the freshwater tilapia Oreochromis niloticus. Environ. Pollut. 2010, 158, 2694-2701. [CrossRef] [PubMed]

22. Pickhardt, P.C.; Stepanova, M.; Fisher, N.S. Contrasting uptake routes and tissue distributions of inorganic and methylmercury in mosquitofish (Gambusia affinis) and redear sunfish (Lepomis microlophus). Environ. Toxicol. Chem. 2006, 25, 2132-2142. [CrossRef]

23. Wang, R.; Wang, W.-X. Importance of speciation in understanding mercury bioaccumulation in tilapia controlled by salinity and dissolved organic matter. Environ. Sci. Technol. 2010, 44, 7964-7969. [CrossRef] [PubMed]

24. Wang, F.; Lemes, M.; Khan, M. Metallomics of mercury: Role of thiol-and selenol-containing biomolecules. In Environmental Chemistry and Toxicology of Mercury; John Wiley \& Sons, Inc.: Hoboken, NJ, USA, 2012; pp. 517-544.

25. Kidd, K.; Batchelar, K. 5-Mercury. In Fish Physiology; Wood, C.M., Farrell, A.P., Colin, J.B., Eds.; Academic Press: Cambridge, MA, USA, 2011; Volume 31, pp. 237-295.

26. Boudou, A.; Ribeyre, F. Experimental study of trophic contamination of Salmo gairdneri by two mercury compounds- $\mathrm{HgCl}_{2}$ and $\mathrm{CH}_{3} \mathrm{HgCl}$-Analysis at the organism and organ levels. Water Air Soil Pollut. 1985, 26, 137-148. [CrossRef]

27. Wang, W.-X.; Wong, R.S. Bioaccumulation kinetics and exposure pathways of inorganic mercury and methylmercury in a marine fish, the sweetlips Plectorhinchus gibbosus. Mar. Ecol. Prog. Ser. 2003, 261, 257-268. [CrossRef]

28. Goto, D.; Wallace, W.G. Influences of prey-and predator-dependent processes on cadmium and methylmercury trophic transfer to mummichogs (Fundulus heteroclitus). Can. J. Fish. Aquat. Sci. 2009, 66, 836-846.

29. Dutton, J.; Fisher, N.S. Bioavailability of sediment-bound and algal metals to killifish Fundulus heteroclitus. Aquat. Biol. 2012, 16, 85-96. [CrossRef]

30. Houck, A.; Cech, J.J. Effects of dietary methylmercury on juvenile Sacramento blackfish bioenergetics. Aquat. Toxicol. 2004, 69, 107-123. [CrossRef] [PubMed]

31. Rodgers, D.; Beamish, F. Dynamics of dietary methylmercury in rainbow trout, Salmo gairdneri. Aquat. Toxicol. 1982, 2, 271-290. [CrossRef] 
32. Li, J.; Drouillard, K.G.; Branfireun, B.; Haffner, G.D. Comparison of the toxicokinetics and bioaccumulation potential of mercury and polychlorinated biphenyls in goldfish (Carassius auratus). Environ. Sci. Technol. 2015, 49, 11019-11027. [CrossRef] [PubMed]

33. Phillips, G.; Gregory, R. Assimilation efficiency of dietary methylmercury by northern pike (Esox lucius). J. Fish. Board Can. 1979, 36, 1516-1519. [CrossRef]

34. Oliveira Ribeiro, C.; Rouleau, C.; Pelletier, E.; Audet, C.; Tjälve, H. Distribution kinetics of dietary methylmercury in the arctic charr (Salvelinus alpinus). Environ. Sci. Technol. 1999, 33, 902-907. [CrossRef]

35. Leaner, J.J.; Mason, R.P. Methylmercury uptake and distribution kinetics in sheepshead minnows, Cyprinodon variegatus, after exposure to $\mathrm{CH}_{3} \mathrm{Hg}$-spiked food. Environ. Toxicol. Chem. 2004, 23, 2138-2146. [CrossRef]

36. Giblin, F.; Massaro, E.J. The erythrocyte transport and transfer of methylmercury to the tissues of the rainbow trout (Salmo gairdneri). Toxicology 1975, 5, 243-254. [CrossRef]

37. Berntssen, M.; Hylland, K.; Julshamn, K.; Lundebye, A.K.; Waagbø, R. Maximum limits of organic and inorganic mercury in fish feed. Aquac. Nutr. 2004, 10, 83-97. [CrossRef]

38. Sandheinrich, M.; Wiener, J. Methylmercury in freshwater fish: Recent advances in assessing toxicity of environmentally relevant exposures. Environ. Contam. Biota Interpret. Tissue Conc. 2011, 2, 169-190.

39. Bloom, N.S. On the chemical form of mercury in edible fish and marine invertebrate tissue. Can. J. Fish. Aquat. Sci. 1992, 49, 1010-1017. [CrossRef]

40. Harris, H.H.; Pickering, I.J.; George, G.N. The chemical form of mercury in fish. Science 2003, $301,1203$. [CrossRef] [PubMed]

41. Trudel, M.; Rasmussen, J.B. Modeling the elimination of mercury by fish. Environ. Sci. Technol. 1997, 31, 1716-1722. [CrossRef]

42. Van Walleghem, J.L.; Blanchfield, P.J.; Hintelmann, H. Elimination of mercury by yellow perch in the wild. Environ. Sci. Technol. 2007, 41, 5895-5901. [CrossRef] [PubMed]

43. Van Walleghem, J.L.; Blanchfield, P.J.; Hrenchuk, L.E.; Hintelmann, H. Mercury elimination by a top predator, Esox lucius. Environ. Sci. Technol. 2013, 47, 4147-4154. [CrossRef] [PubMed]

44. Aberg, B.; Ekman, L.; Falk, R.; Greitz, U.; Persson, G.; Snihs, J. Metabolism of methyl mercury $\left({ }^{203} \mathrm{Hg}\right)$ compounds in man. Arch. Environ. Health 1969, 19, 478-484. [CrossRef] [PubMed]

45. Miettinen, J.K.; Rahola, T.; Hattula, T.; Rissanen, K.; Tillander, M. Elimination of ${ }^{203} \mathrm{Hg}$-methylmercury in man. Ann. Clin. Res. 1971, 3, 116-122. [PubMed]

46. Government of Canada. What Is A Food Guide Serving of Meat and Alternatives? - Canada's Food Guide. Available online: http://www.hc-sc.gc.ca/fn-an/food-guide-aliment/choose-choix/meat-viande/servingportion-eng.php (accessed on 29 November 2016).

47. U.S. Food and Drug Administration. CFR—Code of Federal Regulations Title 21. Available online: https://www.accessdata.fda.gov/scripts/cdrh/cfdocs/cfcfr/cfrsearch.cfm?fr=101.12 (accessed on 29 November 2016).

48. Laparra, J.M.; Velez, D.; Montoro, R.; Barbera, R.; Farre, R. Estimation of arsenic bioavailability in edible seaweed by an in vitro digestion method. J. Agric. Food Chem. 2003, 51, 6080-6085. [CrossRef] [PubMed]

49. Costa, S.; Afonso, C.; Cardoso, C.; Batista, I.; Chaveiro, N.; Nunes, M.L.; Bandarra, N.M. Fatty acids, mercury, and methylmercury bioaccessibility in salmon (Salmo salar) using an in vitro model: Effect of culinary treatment. Food Chem. 2015, 185, 268-276. [CrossRef] [PubMed]

50. Calatayud, M.; Devesa, V.; Virseda, J.R.; Barbera, R.; Montoro, R.; Velez, D. Mercury and selenium in fish and shellfish: Occurrence, bioaccessibility and uptake by Caco-2 cells. Food Chem. Toxicol. Int. J. Publ. Br. Ind. Biol. Res. Assoc. 2012, 50, 2696-2702. [CrossRef] [PubMed]

51. Siedlikowski, M.; Bradley, M.; Kubow, S.; Goodrich, J.M.; Franzblau, A.; Basu, N. Bioaccessibility and bioavailability of methylmercury from seafood commonly consumed in North America: In vitro and epidemiological studies. Environ. Res. 2016, 149, 266-273. [CrossRef] [PubMed]

52. Wang, H.S.; Xu, W.F.; Chen, Z.J.; Cheng, Z.; Ge, L.C.; Man, Y.B.; Giesy, J.P.; Du, J.; Wong, C.K.; Wong, M.H. In vitro estimation of exposure of Hong Kong residents to mercury and methylmercury via consumption of market fishes. J. Hazard. Mater. 2013, 248-249, 387-393. [CrossRef] [PubMed]

53. He, M.; Wang, W.X. Factors affecting the bioaccessibility of methylmercury in several marine fish species. J. Agric. Food Chem. 2011, 59, 7155-7162. [CrossRef] [PubMed]

54. Ouedraogo, O.; Amyot, M. Effects of various cooking methods and food components on bioaccessibility of mercury from fish. Environ. Res. 2011, 111, 1064-1069. [CrossRef] [PubMed] 
55. Costa, S.; Afonso, C.; Bandarra, N.M.; Gueifao, S.; Castanheira, I.; Carvalho, M.L.; Cardoso, C.; Nunes, M.L. The emerging farmed fish species meagre (Argyrosomus regius): How culinary treatment affects nutrients and contaminants concentration and associated benefit-risk balance. Food Chem. Toxicol. Int. J. Publ. Br. Ind. Biol. Res. Assoc. 2013, 60, 277-285. [CrossRef] [PubMed]

56. Burger, J.; Dixon, C.; Boring, S.; Gochfeld, M. Effect of deep-frying fish on risk from mercury. J. Toxicol. Environ. Health 2003, 66, 817-828. [CrossRef] [PubMed]

57. Torres-Escribano, S.; Ruiz, A.; Barrios, L.; Vélez, D.; Montoro, R. Influence of mercury bioaccessibility on exposure assessment associated with consumption of cooked predatory fish in Spain. J. Sci. Food Agric. 2011, 91, 981-986. [CrossRef] [PubMed]

58. Perelló, G.; Martí-Cid, R.; Llobet, J.M.; Domingo, J.L. Effects of various cooking processes on the concentrations of arsenic, cadmium, mercury, and lead in foods. J. Agric. Food Chem. 2008, 56, 11262-11269. [CrossRef] [PubMed]

59. Armbruster, G.; Gutenmann, W.H.; Lisk, D.J. The effects of six methods of cooking on residues of mercury in striped bass. Nutr. Rep. Int. 1988, 37, 123-126.

60. Gutenmann, W.H.; Lisk, D.J. Higher average mercury concentrations in fish fillets after skinning and fat removal. J. Food Saf. 1991, 11, 99-103. [CrossRef]

61. Blanco, S.L.; Gonzalez, J.C.; Vieites, J.M. Mercury, cadmium and lead levels in samples of the main traded fish and shellfish species in Galicia, Spain. Food Addit. Contam. 2008, 1, 15-21. [CrossRef] [PubMed]

62. Chen, M.H.; Teng, P.Y.; Chen, C.Y.; Hsu, C.C. Organic and total mercury levels in bigeye tuna, Thunnus obesus, harvested by Taiwanese fishing vessels in the Atlantic and Indian Oceans. Food Addit. Contam. 2011, 4, 15-21. [CrossRef] [PubMed]

63. Groth, E. Ranking the contributions of commercial fish and shellfish varieties to mercury exposure in the United States: Implications for risk communication. Environ. Res. 2010, 110, 226-236. [CrossRef] [PubMed]

64. Moon, H.B.; Kim, S.J.; Park, H.; Jung, Y.S.; Lee, S.; Kim, Y.H.; Choi, M. Exposure assessment for methyl and total mercury from seafood consumption in Korea, 2005 to 2008. J. Environ. Monit. 2011, 13, 2400-2405. [CrossRef] [PubMed]

65. Tran, N.L.; Barraj, L.M.; Bi, X.; Schuda, L.C.; Moya, J. Estimated long-term fish and shellfish intake-National Health and Nutrition Examination Survey. J. Expo. Sci. Environ. Epidemiol. 2013, 23, 128-136. [CrossRef] [PubMed]

66. Afonso, C.; Costa, S.; Cardoso, C.; Oliveira, R.; Lourenco, H.M.; Viula, A.; Batista, I.; Coelho, I.; Nunes, M.L. Benefits and risks associated with consumption of raw, cooked, and canned tuna (Thunnus spp.) based on the bioaccessibility of selenium and methylmercury. Environ. Res. 2015, 143, 130-137. [CrossRef] [PubMed]

67. George, G.N.; Singh, S.P.; Prince, R.C.; Pickering, I.J. Chemical forms of mercury and selenium in fish following digestion with simulated gastric fluid. Chem. Res. Toxicol. 2008, 21, 2106-2110. [CrossRef] [PubMed]

68. Dunn, J.D.; Clarkson, T.W.; Magos, L. Ethanol reveals novel mercury detoxification step in tissues. Science 1981, 213, 1123-1125. [CrossRef] [PubMed]

69. Chapman, L.; Chan, H.M. The influence of nutrition on methyl mercury intoxication. Environ. Health Perspect. 2000, 108, 29-56. [CrossRef] [PubMed]

70. Shim, S.M.; Ferruzzi, M.G.; Kim, Y.C.; Janle, E.M.; Santerre, C.R. Impact of phytochemical-rich foods on bioaccessibility of mercury from fish. Food Chem. 2009, 112, 46-50. [CrossRef]

71. Passos, C.J.; Mergler, D.; Gaspar, E.; Morais, S.; Lucotte, M.; Larribe, F.; Davidson, R.; de Grosbois, S. Eating tropical fruit reduces mercury exposure from fish consumption in the Brazilian Amazon. Environ. Res. 2003, 93, 123-130. [CrossRef]

72. Laird, B.D.; Shade, C.; Gantner, N.; Chan, H.M.; Siciliano, S.D. Bioaccessibility of mercury from traditional northern country foods measured using an in vitro gastrointestinal model is independent of mercury concentration. Sci. Total Environ. 2009, 407, 6003-6008. [CrossRef] [PubMed]

73. Laird, B.D.; Chan, H.M. Bioaccessibility of metals in fish, shellfish, wild game, and seaweed harvested in British Columbia, Canada. Food Chem. Toxicol. Int. J. Publ. Br. Ind. Biol. Res. Assoc. 2013, 58, 381-387. [CrossRef] [PubMed]

74. Aduayom, I.; Campbell, P.G.C.; Denizeau, F.; Jumarie, C. Different transport mechanisms for cadmium and mercury in Caco-2 cells: Inhibition of $\mathrm{Cd}$ uptake by $\mathrm{Hg}$ without evidence for reciprocal effects. Toxicol. Appl. Pharm. 2003, 189, 56-67. [CrossRef] 
75. Rostami-Hodjegan, A. Physiologically based pharmacokinetics joined with in vitro-in vivo extrapolation of ADME: A marriage under the arch of systems pharmacology. Clin. Pharmacol. Ther. 2012, 92, 50-61. [CrossRef] [PubMed]

76. Berntssen, M.H.; Hylland, K.; Lundebye, A.K.; Julshamn, K. Higher faecal excretion and lower tissue accumulation of mercury in Wistar rats from contaminated fish than from methylmercury chloride added to fish. Food Chem. Toxicol. Int. J. Publ. Br. Ind. Biol. Res. Assoc. 2004, 42, 1359-1366. [CrossRef] [PubMed]

77. Sherman, L.S.; Blum, J.D.; Franzblau, A.; Basu, N. New insight into biomarkers of human mercury exposure using naturally occurring mercury stable isotopes. Environ. Sci. Technol. 2013, 47, 3403-3409. [CrossRef] [PubMed]

78. Hur, S.J.; Lim, B.O.; Decker, E.A.; McClements, D.J. In vitro human digestion models for food applications. Food Chem. 2011, 125, 1-12. [CrossRef]

79. Laird, B.D.; Weiseth, B.; Packull-McCormick, S.R.; Peak, D.; Dodd, M.; Siciliano, S.D. Solid-liquid separation method governs the in vitro bioaccessibility of metals in contaminated soil-like test materials. Chemosphere 2015, 134, 544-549. [CrossRef] [PubMed]

80. Rowland, I.R.; Davies, M.J.; Evans, J.G. Tissue content of mercury in rats given methylmercuric chloride orally: Influence of intestinal flora. Arch. Environ. Health 1980, 35, 155-160. [CrossRef] [PubMed]

81. Rowland, I.R.; Robinson, R.D.; Doherty, R.A. Effects of diet on mercury metabolism and excretion in mice given methylmercury: Role of gut flora. Arch. Environ. Health 1984, 39, 401-408. [CrossRef] [PubMed]

82. Basu, N.; Goodrich, J.M.; Head, J. Ecogenetics of mercury: From genetic polymorphisms and epigenetics to risk assessment and decision-making. Environ. Toxicol. Chem. 2014, 33, 1248-1258. [CrossRef] [PubMed]

(C) 2017 by the authors; licensee MDPI, Basel, Switzerland. This article is an open access article distributed under the terms and conditions of the Creative Commons Attribution (CC BY) license (http:/ / creativecommons.org/licenses/by/4.0/). 